https://doi.org/10.18485/cosic_dobrica.2018.ch9

821.163.41.09-31 Ћосић Д.

\author{
ДУШКО Н. БАБИЋ* \\ Филолошка гимназија \\ Београд
}

\title{
ИСТОРИЈА И РАЗИСТОРИЈА У РОМАНУ ГРЕШНИК ДОБРИЦЕ ЋОСИЋА
}

\begin{abstract}
У овом раду испитивано је разумевање историје Добрице Ћосића у светлу идеја из његовог романа Бајка. У неколико фантазмагоријских парабола, посебно у поглављу Разистиорија, Ћосић сугерише негативно виђење историје као непрекидног смењивања изневерених очекивања, насиља, зла. У контексту овако постављене историозофије анализиран је роман Грешник, из трилогије Време зла. Сагледавши трагични ток српске историје у светлу своје песимистичке историозофије, Ћосић сугерише начине супротстављања безизлазу историје, кроз повратак примордијалним импулсима живота, које налази у природи и у дубини народне душе.
\end{abstract}

Кључне речи: Бајка, Грешник, Време зла, историја, разисторија, време, партија, тоталитаризам, природа, народ.

1. Целокупно књижевно дело Добрице Ћосића резултат је његове загледаности у српску историју. Та оцена односи се како на његове романе, тако и на мемоарску и есејистичку прозу. Није претерано рећи да је историја српског народа, сагледана из различитих углова и у различитим контекстима, била његова основна, ако не и једина књижевна тема. Трагање за скривеном, дубинском истином, за коренима и судбинским токовима у новијој историји српске државе и српског народа јесте основни интелектуални и књижевни задатак који је Ћосић држао испред себе целог живота. ${ }^{1}$ Разумевање народне душе и судбине, као и питања људског постојања уопште, Ћосић је увек везивао за историјско време, за конкретне историјске догађаје, процесе и личности. То је био темељ његовог погледа на свет и на књижевност. Зато се у насловима његових романа тако често, скоро опсесивно, јавља реч време.

*dusko.babic@yahoo.com

1 „Ако не откријем нека универзална својства људског трагизма на српској земљи, Време власти и неће имати значаја" (Ћосић 2008: 86). 
У том смислу, Ћосић је можда најбољи пример оне познате тезе по којој је „српска књижевност судбински обележена историјом” (Деретић 1981: 24). О томе речито сведочи и наслов једне Ћосићеве позне, мемоарско-есејистичке, исповедне књиге: Исйорија као суgбина.

Опсесивно везивање за историју, са циљем да се сагледају њени скривени токови и закони, да се у слици историјских збивања и процеса допре до истине у којој су сливени национално и општељудско, пресудно је утицало на формирање поетичких доминанти Ћосићевих романа. А међу њима је лако уочљива склоност да се у фабулативно-фикционалну структуру уносе есејистичко-филозофске деонице, у којима се сучељавају и објашњавају различита разумевања историјских, политичких и идеолошких становишта. Склоност да уметничко обликовање историјских тема подупире дискурзивним, у бити нелитерарним средствима, најблаже речено, није увек била на услузи уметничкој убедљивости његових романа и у критици је била предмет оспоравања.

Промишљање историје, тражење закономерности у конкретним догађајима и појавама, откривање опште основе историјских збивања, Ћосић, чини се, није могао да избегне а да не изневери самог себе. Иза ликова, идеја, приказа историјских личности и догађаја видимо један филозофски напор да се разуме историја српског народа и историја уопште. Односно, целокупни Ћосићев романескни опус прожет је тежњом да се свет фикције утемељи на личној филозофији истиорије. Ту филозофију налазимо распршену у свим његовим романима - у дијалозима, монолозима и наративним коментарима, а уметнички фокусирану, уцеловљену и продубљену у његовом алегоријском роману - Бајка.

Рад који следи представља покушај да се идеје о историји из овог романа повежу са конкретним обрадама историјских тема Добрице Ћосића, са посебним освртом на роман Грешник.

2. На први поглед, Бајка делује као „страно тело” међу Ћосићевим романима. По теми, ликовима, радњи, композицији, стилу и језику, овај, четврти по реду Ћосићев роман разликује се од оних који су му претходили (Корени, Деобе, Далеко је суние), као и од оних који су следили после њега (Време смрйи, трилогија Време зла - Грешник, Верник,

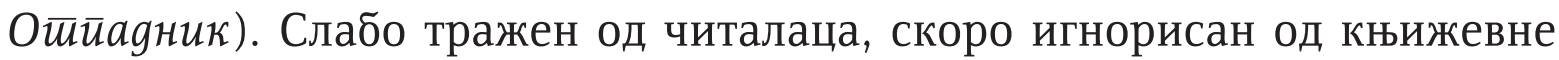
критике, овај роман је дуго гуран на маргину Ћосићевог књижевног опуса. Непријемчива и са естетске и са идеолошке стране, Бајка је захтевала другачијег читаоца од оног којем се обраћао у својим осталим романима - пажљивијег, литерарно и филозофски опремљенијег; читаоца који ће бити способан да сложену асоцијативност ове алегоријске сатире сагледа не само у контексту савременог историјског тренутка (роман је настајао почетком шездесетих година прошлог века, први пут објављен 
1965) него и на фону „фаустовских” питања и идеја о смислу и смеру постојања, о злу као сталном пратиоцу историје. Рецепција овог романа тражила је широк опсег знања и питања, постављених у Старом и Новом завету, као и њиховог литерарно-филозофског актуелизовања код Гетеа, Мана, Достојевског, Орвела, Замјатина итд.

Временом се став о овој књизи постепено мењао, па је њена рецепција прешла пут од маргинализовања до става да се без ње „не може разумети целокупно Ћосићево стваралаштво" (Крстић 2010: IX).

Животну и идејну основу Бајке Ћосић је образложио у једном запису, замишљеном као скица за предговор издању из 1984, од којег је одустао, а који је касније у целини дат као део поговора издања из 2010, у Колу СКЗ. „Идеолошко лицемерје је прожело сав јавни говор. Све је постало лаж. Сви су циљеви били лажно означени... На почетку шесте деценије у мени је коначно умирао 'идеолошки човек' - марксист, стаљинист, титовац... Прелаз у други табор, у 'слободни свет', у коме су, највероватније, привремено угашени крематоријуми, у свет егоизма и лицемерја - није ми обећавао спасење" (Ћосић-Вукић 2010: 370-371). Бајка је тражење излаза из „празног простора” у којем је писац затечен у време „изласка из строја" Партије, почетком шездесетих прошлог века, између заблуде о „комунистичком рају” и химера о „европском хуманизму". Ни у једном ни у другом није било сигурног људског пута, испуњења људског сна о правди, истини, слободи. „Ниче је у праву: Бор

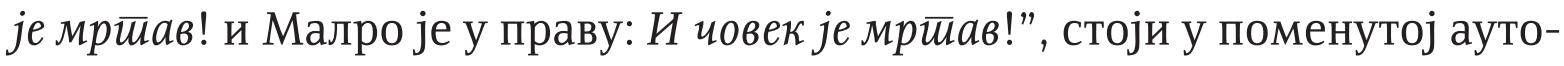
биографској белешци (Ћосић Вукић 2010: 371).

„Шта човек сада није, шта не сме да учини, шта сутра не може бити?" (Ћосић 2010: 21) - гласи основно питање које се лајтмотивски провлачи кроз цео роман, на које човек не зна одговор, па га поставља ђаволу. Може ли људско трајање у времену бити слободно кретање ка остваривању свих жеља и освајању нових уживања? Смеју ли се на земљи јести „све јабуке”? Шта је историја људског рода у својој суштини: освајање и акумулирање добра, или смењивање варијација зла - неправди, тлачења, лажи, илузија? Одговори које роман сугерише су песимистички, суморни. Фаустовска погодба између човека и моравског ђавола Анђаме, по којој ће заменити места, остварује се, на крају, без великих напора и ломова. Ђаво лако прихвата благодети градског живота и препушта им се без остатка. Човек добија вечност на дну реке времена, осуђен да вечно трага за белутком на којем су уписани одговори на питања која га прогоне. Ништа се суштински није променило: улазак ђавола међу људе није се ни осетио, јер је свет уређен по ђаволским мерама и потребама. Људско и ђаволско нису ни у каквом сукобу.

Овакви одговори сугерисани су причама утканим у структуру Бајке и густом мрежом симбола, међу којима средишње место заузимају 


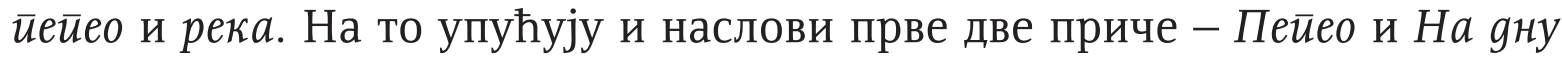
реке. Читав роман је замишљен као страшни сан, у којем је Човек-приповедач заноћио у некој „небилији”, под туђим кровом, и где га је пробудила „огромна стена тишине". Када се пробуди, све чега се дотакне постаје пепео. Простор у којем се обрео јесте простор страха од света и од себе самога. Човек је тако дошао до тачке у којој спознаје да у свету нема ничег постојаног, да не постоји сила која чува поредак, вредности, освојена добра, културу, цивилизацију, законе по којима се живи. Једина извесност живота јесте пепео - пропадање, нестајање. Зато Човек радосно урања у „своју реку”, са надом да ће тамо наћи људе, нестале купаче, одговоре који га муче. Али, и тамо налази пустош и - ђавола. Пепео и река су два симболична имена протицања и нестајања, „гробница историје и људи" (Ћосић 2010: 11).

Овакво виђење историје Ћосић нуди у својим антибајкама из романа Бајка-Mиsеuт, Камонија и Разистиорија. У овој последњој Ћосићева антиутопијска слика света носи најснажније и за наше истраживање најважније поруке. У причи је ухваћен тренутак „космичког акцидента” - „квазијарне ерупције”, када настаје „завера часовника” и време прво „одбија да пролази", а затим крене уназад. Историја креће реверзибилним током, догађаји се одвијају уназад, све што постоји улази у ток унепостојавања и креће се ка свом почетку. Бивање прелази у небивање, историја у разисторију. Све што је постојало и што постоји претвара се у пепео. Историја није колевка у којој се одгаја ново, више и боље, него гробница која гута човека и његове творевине.

Ово су слике и идеје које, у алегоријском кључу, посредују Ћосићеву идеју историје. У основи те идеје јесте уверење да историја својом суштином негира свако телеолошко (сврховито) поимање. Њоме не управља никаква промисао која јој је надређена, а у њој самој нема саморазвоја у смеру напредовања човека и човечности. Ход времена не поправља човека, напротив, удаљава га од његових исконских моћи и разара вредности које је мукотрпно градио у прошлим вековима. Историја није човекова учитељица живота, у њој не делује сила добра. Историја је смењивање сила деструкције, ланац зла, у којем се смењују облици обмана и самообмана. Андрићевски речено, свет је „крива Дрина” коју никад нећемо исправити и коју никад не смемо престати да исправљамо.

Духовно исходиште ове историозофије књижевни историчар Милан Радуловић, сасвим основано, види у гностичкој космогонији. „Зло, патња и страх првородне су енергије живота, како их види овај уметник. [...] Зло, патња и страх покренути су неком прадавном преваром која се догодила при самом рађању времена" (Радуловић 2007: 189). Хармонија првобитног духовног постојања, односно непостојања у материји и вре- 
мену, нарушена је када је зли демијург створио свет - а то значи и свест о времену, односно историју. У ток историје, у њен почетак и суштину, пројектована је превара, лажно обећање на које је човек насео.

У позадини ових суморних представа о историји, долази питање које човек не може и не сме да заборави: где је избављење? Одговор или, боље рећи, могућност одговора одзвања у честом понављању по-

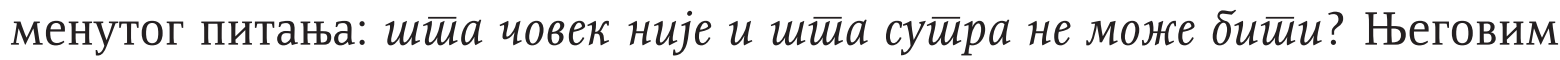
понављањем сугерише се вера да постоји простор људскости који треба препознати и „оградити" законима и забранама, пред којима ће се поклонити све идеологије и политичке борбе. Пронаћи и сачувати то светло језгро живота значи наћи човека и човечност, светли белутак на дну реке времена.

3. Уметничке конкретизације оваквог разумевања историје наћи ћемо у свим Ћосићевим романима. У том смислу је оправдано посматрати Бајку као средишњи део целокупног Ћосићевог књижевног опуса. Идеју историје изграђену у алегоријској антиутопији Бајке, Ћосић је уграђивао у своје ликове, слике историјских догађаја и личности, разумевање историјских процеса.

Основни увид о суштини историјског тока човечанства, по којем се историја види као континуитет деструктивних, човеку ненаклоњених сила, пројектован је на целокупну сагу о шумадијској породици Катић, од Корена (1954) до Времена власиии II (2007). И то се јасно види у насловима Ћосићевих дела: у двочланим генитивним синтагмама, уз основну

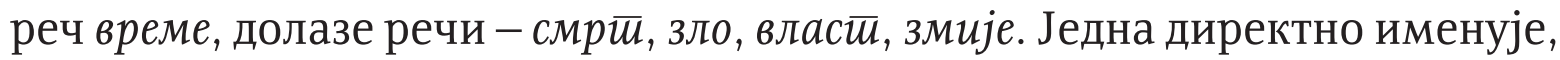
а друге асоцирају зло. Свако време је, мање или више, овако или онако, време зла. Зашто је само једно директно именовано као време зла? То је управо онај период српске и опште историје у којем се за своја младалачка уверења борио писац Добрица Ћосић, када су велике револуционарне идеје о правди и слободи узбуркале свет и милионе занесених душа; време у којем је писац не само интелектуално, критичком мишљу, него искуствено и животно, спознао да је следбеник и верник једне брутално тоталитарне идеологије, која својом праксом директно поништава све своје прокламоване циљеве - слободу, правду, једнакост. Судбину народа писац је видео у себи, и, обрнуто, себе у судбини народа.

Из тог разочарања и слома, који се догодио почетком шездесетих прошлог века, настала је Бајка, као идејна, филозофска основа уметничког обликовања српске историје од краја XIX до краја XX века, конкретизована у причи о четири генерације породице Катић.

У мноштву ликова које Ћосић уводи у ту грандиозну причу, централно место, не само у Времену зла него у целој саги о Катићима, заузима Иван Катић. Окосницу Времена зла чини рукопис његових есејистичко-филозофских сећања, у којима се његовим погледом откривају 
људи и догађаји увезани у основни фабулативни ток романа. Није тешко приметити да су у књизи коју саставља Иван Катић заступљена управо она историјска и идеолошка питања која Ћосић у поменутој скици за предговор роману Бајка наводи као личне разлоге „изласка из строја”. Иван Катић је глас писца, не само у Времену зла него у целокупној Ћосићевој слици српске историје. ${ }^{2}$ Он је њен најдубљи тумач и тежиште њеног најдубљег трагизма. У лик Ивана Катића пројектована су уверења, искуства и живот Добрице Ћосића - његови револуционарни заноси, побуна и дисидентска борба; верник, грешник и отпадник Партије. Кроз Ивана Катића уметнички је конкретизована песимистичка филозофија историје из алегоријских фантазмагорија Бајке.

Оно што је почетком шездесетих видео у општем току светске револуције и на основу чега је градио своје космогонијске представе о устројству човека, времена и света, Ћосић је искористио као идејну основу за демитологизацију титоизма и „званичне историје КПЈ” (Јеремић 2002: 322) у Времену зла и Времену власиич. Бајка је настала из искуства верника којег је нагризла сумња, а Време зла, двадесетак година касније, из искуства дисидента-отпадника у којем су се сабрала и искристалисала искуства верника и грешника. Космогонијско зло, настањено у човеку и у историји, показало се изблиза, као животна реалност српског народа у време када је упао у „бољшевичку маглу”.

Ћосићево вићење српске историје XX века, дато у грандиозној романескној саги о породици Катић, своје идејно и историозофско средиште има у роману Бајка. Општи увиди о свету, времену, човеку, обликовани у параболичним сликама овог романа, конкретизовани су у уметничком презентовању српске историје преплетене са животним путем самог писца. Тај преплет најизразитији је у Времену зла, тако да није претерано рећи да су ови романи и историјски и исповедни.

Историју српског народа од Берлинског конгреса наовамо Ћосић види као остварење мрачне гностичке историозофије из романа Бајка. Историју Срба и српски менталитет он је искористио као „материјал” за конкретизацију и постварење представе о историји као сталном преплету великих обећања и изневерених нада. Човечанство у целини жртва је „кривог почетка”, „пројектоване грешке” трајања у времену. Неки народи су градили механизме одбране, а неки су се препуштали деструктивним законима историје. У ове друге спадају и Срби. У бићу српског

${ }^{2}$ O посебном стасу овог књижевног јунака у Ћосићевим романима говоре и пишчеве дневничке белешке, где му се често враћа, откривајући са колико пажње и посвећености је градио тај лик. „Сутра са Момом Капором и Велимиром Вукадином путујем у Венецију да нешто конкретно дочарам и доживим - седам последњих дана и ноћи Ивана Катића у Венецији" (Ћосић 2010: 24). 
народа има нешто што га чини неотпорним и неспремним да избегне најгоре путеве и да искористи своје виталне, државотворне потенцијале. „Срби су сами својом рођеном снагом створили своју државу [...] ни династичку ни сталешку, но искључиво своју, само народну и националну" (Скерлић 1964: 25). Али, та слободарска енергија народа, која је створила своју слободу и своју државу у бунама и ратовима, у миру би остајала без оријентира и покретача и заплитала би се у самодеструкцију. О томе говори она, често цитирана Ћосићева реченица, по којој Срби у миру изгубе све што остваре у рату.

Силе деструкције преплавиле су српски народ и његову историју у најтрагичнијем облику у „тунелу бољшевизма”. Комунистичка идеологија, коју њен следбеник и верник Добрица Ћосић временом спознаје као епохалну лаж, представља отелотворење, квинтесенцију космогонијских и историозофских идеја из Бајке.

Комунизам као идеологија заводљивих обећања о правди и једнакости нашла је плодно тле у бићу и менталитету српског народа, у „косовској мисли" (И. Андрић) и на њој заснованој митологији која говори о томе да је као највише мере људског остварења српски народ видео у жртви за високе идеале „царства небеског”. Комунистиичку уйойију срй-

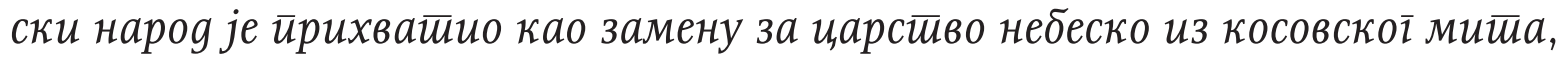
а ауторитет партије и партијског вође као замену за вредности светосавског православља и Бога. Исконске, животворне снаге које су оформиле свест о посебности српског народа и које су га одржале у дугим вековима ропства, замењене су њиховим сурогатима и изопачењима. Истину је заменила илузија, народ је поведен на странпутицу, у историјску маглу у којој није видео своје вековне оријентире. Прихватање приче о „комунистичком рају" значило је прихватање живљења по правилима идеологије која своје основне идеале - слободу, правду, једнакост - изокреће у њихове супротности - у бруталну тиранију, неправду, потчињавање.

„Анђео комунизма” је аждаја која ватром из својих уста уништава достојанство човека, која „не уважава тајну људског бића” (Ћосић 2002: 246). Комунистички рај је у стварности пакао, у којем је „погинуо човек” и човечност. Чини се да је последњи, најдубљи круг тог пакла затвор за међуратне комунисте, двострука робија, „комунистички универзитет”, где заробљени комунисти подвргавају тортури своје чланове, приводећи их „истинској вери” Партије. О томе говори неколико поглавља „унутрашњег романа" који саставља Иван Катић, утканих у роман Грешник. У њима је дато драматично сведочанство о најдубљој тачки људског пада у мраку чудовишног тоталитаризма - смрт мишљења, истине, вере, породице, човека, светиње живота. Тачка у којој се чини да се срушило све на чему се одржава живот, тренутак кад је историја у страшном убрзању кренула уназад и постала разисторија. Тако је дошла до свог тамног 
прапочетка, кад је зли демијург устројио свет и посејао у човека лажну наду. Није тешко видети да је истина до које је Ћосић дошао на трагу и у оквирима историозофије из Бајке.

Сагледана на нивоу националне историје, а то је основна тематска раван Ћосићевих романа, идеја разисторије сугерише странпутице и посртања Срба, у временима када су конституисани као политички народ, у властитој држави. Загледан у родно тле, у корене менталитета и судбине народа, у време кад се смело гледати само напред, погледом идеолошког оптимизма, Ћосић уноси енергију субверзије у нашу прозу друге половине XX века. Ту се непорециво показала његова блискост са народом и народном душом, легитимисала се суштина како његовог национализма, тако и исходиште његове стваралачке енергије. Из такве позиције он је откривао и скривене законитости српске историје, у којој је уз конструктивну, слободарску народну снагу, увек ишла сила деструкције и разарања, испољавана у деобама и поделама. Друштвена раслојавања јесу неминовна у сваком народу и времену, и људско трајање у времену не може се ни замислити без њих. Али, у српском народу она у себи носе димензију усудног и трагичног, унутрашњег проклетства са којим не успевамо да се изборимо. На такву подлогу пало је заводљиво обећање комунизма и силе деструкције у народу довело до усијања. Ген националних gеоба gошао је у йраїинни сйој са ияеолошким фанайизмом, који је у сукобу рођен и од сукоба живи. Трагична располућења јавила су се у мноштву облика. Захватила су само језгра живота - породицу. На различитим странама идеолошких барикада нашли су се синови и очеви, сестре и браћа. Мајке више не познају своје синове, под истим кровом струји прастара, словенска и српска, породична солидарност и идеолошка острашћеност. Породица Катић је оличење тог усуда, метафора целог народа.

Идеолошки фанатизам и слепило тоталитаризма нагризли су и изопачили оно најбоље у бићу народа - енергију отпора тлачитељу претворили су у сурови фанатизам, породично и национално осећање у верност апстрактном, мамонском божанству - Партији. Породица и народ, темељне одреднице идентитета, утопљене су у безбојно, илузионистичко партијско братство.

Као алтернатива овом историјском путу, у роману Грешник, као и у Времену зла у целини, видимо монденски предратни Београд, оличен у кругу Ивановог ујака Најдана Тошића. Свет занесених револуционара и однарођених буржујских дендија у роману теку паралелно, суштински далеко један од другога. Први, револуционарни је острашћен и прегрејан, други дегенерисан у свом егоизму и индиферентности за све што прелази границе личног комодитета и уживања. Тај буржујски Београд, заљубљен у Европу, салоне, технику, аутомобилске трке, профит и сл., 
у Ћосићевој слици Србије толико је несимпатичан и љигав, да се јасно - можда и сувише јасно и понекад науштрб уметничке уверљивости - види негативан став писца о њему.

Који пут треба да следи човек, појединац и српски народ као целина? Сагледана у контексту историозофије Бајке, као и тренутка у којем је она настала, ово питање у роману Грешник остаје отворено. Роман својом целином сугерише поруку да је у XX веку историја разоткрила своје негативно лице и да су путеви који се нуде човеку странпутице и злопутице.

4. Ако нема јасно трасираног историјског пута, има ли уопште неког излаза и ослонца за човека и његову наду? Види ли писац излаз из овог идеолошког беспућа?

У роману Грешник издвајају се два „јака" места, у којима се сугеришу могући одговори, на опшељудском и националном плану: последње поглавље романа које говори о љубавној авантури Милене Драговић и Петра Бајовића на неком грчком острву и део „унутрашњег романа” Ивана Катића у којем је приказан живот Срба-логораша на острву Златни врт, у аустроугарском логору Нађмеђер, у Словачкој.

Последње поглавље сугерише разрешење полазећи од људске природе, од човека уопште. У бајковити, аркадијски предео неког грчког острва беже Петар Бајовић и жена његовог партијског друга Богдана Драговића, Милена. И једно и друго схватају да су служећи партији изгубили властити живот, да су жртвом за више циљеве изневерили себе и дошли до тачке кад је живот лишен смисла и лепоте. Петар Бајовић, војник Коминтерне, егзекутор издајника и троцкиста, после једне погрешне егзекуције, покушава да побегне из тог огавног света, у страху да и њега не стигне свеприсутна рука Партије и да проживи бар један дан среће. Милена Драговић, после деценија жртвовања каријере револуционара-фанатика, свог мужа Богдана Драговића, схвата да нема ни мужа, ни сина, ни породице, да је у таквом животу не чека обичан срећан људски дан. Зато се одазива безумном, очајничком Петровом позиву да побегну на „Јоанидисово острво”. Ту, на острву, међу козама, маслинама, лимуновима, окружени морем, под медитеранским сунцем, у еденској слободи и лепоти, они живе неколико дана пуног живота и истинске среће. У крилу природе, препуштени природним нагонима и њиховом природном испољавању, они побеђују зло историје - политику и идеологију. Као да се човек у њима враћа себи, својој праоснови и потенцији. Али, срећа пронађена на острву тренутна је, траје колико и бег од људи и вртлога политике. Тренуци истинске среће су острвца љубави и лепоте у океану ускраћености, сивог, невеселог постојања. И Милена и Петар то знају и прекидају своје еденске тренутке неумитним поврат- 
ком. Свесни су да другог пута нема. Она се враћа у своју разорену породицу, из које је, по налогу Партије, одавно отишао муж, из које, његовим трагом, одлази син Владимир, где је чека усамљени и одбачени отац и дезоријентисани брат. Он се враћа у централу Коминтерне да ликвидира издајнике, да сам непрестано буде на нишану неке крваве руке, налик његовој. Али, боравак на острву доноси им нешто што им нико не може

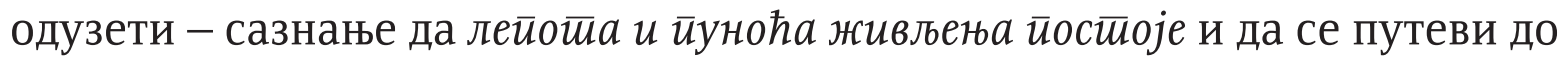
њих налазе у човеку самом, а не у револуцијама и идеологијама.

Идејна основа за овакав завршетак романа, односно за разумевање историје сугерисано у њему, налази се у русоовској представи о аркадијској чистоти претцивилизације. На то упућује симболика мирног, забаченог острва на којем су сачувани исконски односи човека и природе, где живот протиче несвестан своје примордијалне хармоничности, заштићен изолованошћу и даљином од изопачених тековина цивилизације. Русоовска идеја човека у крилу природе и природних потреба и нагона, очигледно је постављена као допуна идеји историје изведене из гностичког учења о „лажном обећању” на почетку времена, датој у антиутопијској параболи Бајке.

У сусрету те две идеје сугерише се виђење живота по којем је срећа тренутна и несигурна, острвце времена окружено океаном патње и неслободе. Човеку цивилизације није суђено да дуго ужива у тој срећи, јер је од ње суштински одвојен. Човек као да не може да са себе збаци своје бреме, оно је постало део његовог бића. Не постоји склониште од времена и његових налога, немогуће је побећи из историје, али је исто тако немогуће уништити наду да места људске среће и пуноће живљења ипак постоје. И што је још лепше и утешније: та острва среће нису неки далеки простори - они су део човека и живота.

На трагу те идеје изграђена је и епизода о животу српских логораша из Великог рата, на дунавском острву Златни врт. Командант логора, пуковник Валмер, Србе третира као марву, коју буквално упреже у јарам да оре, дрља, вуче запрегу са репом и ђубретом. Али, од физичког мучења „у коњском животу”, о којем прича робијаш и роб Иван Катић, људима теже пада сазнање да је логор „систем за понижавање и поништавање човека" (Ћосић 2002: 40). Србима је забрањено све што припада човеку: не смеју чак ни да се убију, јер то је частан чин, како каже мучитељ Фон Бенедикт. У том неђмеђерском паклу обесмишљена је свака нада, убијена свака врлина, човек је постао равнодушан и на живот и на смрт. У логорашима је убијена свака помисао да се уздигну и побуне, да покажу да су нечији синови и очеви, да су људска бића. Све се промени једног дана када се неко досети да неком чича Милоју са Дурмитора, народном певачу, направе гусле. И сви као један дају се на скупљање материјала. Као да зидају град. Најтеже иде са струном: неки 
Милојко Рудничанин осмели се да из репа „неђмеђерског коња начупа пуну шаку". Подухват плати главом, са оптужбом да је ухваћен у содомији. Али, жртва није узалудна: једног дана, „на свету неђељу”, на сред логорског круга, одјекне страшни лелек чича Видоја: „Боже мили, чуда великога". Пушке и митраљези брзо прекину песму, на месту светковине остану лешеви, међу њима и чича Милоје. Али, у том поразу робови, једни пред дугима, и сами пред собом, осете препорађајућу моћ слободе, нађу разлог за наду. Иван Катић, онај који све ово гледа и бележи, каже: „Тог јутра, и једино тога сунчаног јесењег дана [...] сви су ми моји сународници заиста били браћа. Нико подлац. Нико бездушник. Било је то јединствено испољавање припадности нечем значајнијем и вечнијем од нас самих: припадности људској заједници и народу који не пристаје на уништење. У ствари, била је то свест кишне капи да пада у океан" (Ћосић 2002: 60).

Епизода са чича Милојем у паклу неђмеђерског логора иде у ред најдубљих и најлепших страница у целокупној Ћосићевој прози. Оне призивају у сећање и у дубље промишљање места са сличном темом из дела неколико великих српских писаца - Андрића, Лалића, Вука и сл. Гусле, као симбол националног трајања, изнутра препорађају изгубљеног појединца, као Ивана Катића, пониженог роба, париског студента и господског сина. „Ту око чича Видоја, слушајући десетерац, који ја, иначе, нисам дотле много волео, ми смо успостављали духовно братство и свој национални идентитет" (Ћосић 2002: 60).

Ова епизода баца ново светло на Ћосићево разумевање историје и човековог трајања у времену. Снагу да се супротстави унепостојавању и разисторији, растакању живота у времену, човек налази у вези са другим људима исте судбине, језика, песама, жртава. Свест капи да је део океана осмишљава и њено сићушно постојање, уграђујући га у нешто велико. Национално осећање везује човека за саме основе живота, у њему се сабирају његове дубинске моћи, проговара снага достојанства живота и тежња за овековечењем у времену. То је сржна порука приче о васкрсењу наде и људскости на острву зла, у Златном врту разисторије, слици и прилици резултанте прогреса двадесетог века. Без тог оквира, без снаге коју симболизује десетерац, који је „што и платно Боланом Дојчину", како рече један српски песник, живот је пустиња, а човек близу тачке када му је свеједно хоће ли бити човек или марва.

Овде се намеће потреба повезивања симболике два острва из романа Грешник - Јоанидисовог острва љубави и аустроугарског логора за ратне заробљенике, Златног врта. Лако је уочити њихов контрастни однос: на једном човек нема господара, осим сунца и земље; на другом човек цивилизације уљуђује балканског дивљака средствима која неги- 
рају и цивилизацију и човека. На Јоанидисовом острву види се шта је човек у својој првотности и шта је могао бити да га нису кроз историју усрећивале и уљуђивале идеје прогреса; у Златном врту види се резултат историјског хода, човек који је у свом искуству акумулирао „благодети" цивилизацијског развоја. Све појачава горка иронија уграђена у име логора. Своја мрачна дела човечанство је научило да заогрће у лепа, златна имена. Контрастни доживљај два острва у роману даје невеселу слику двадесетог века, али и целокупне историје људског рода, која човека није водила у добром правцу. Историја нас није приближила одговору на основно питање из Бајке: шта човек није и шта никад не сме да буде. Историја није учитељица знања: гомилањем научних и техничких знања, потчињавањем природних закона својим потребама, ми не поправљамо овај свет, јер не поправљамо себе. Човек је пристао на зло и више као да не тражи путеве добра. Историја није укинула поделу на мучитеље и мучене, џелате и жртве, робове и робовласнике. Само је тој подели дала нове облике и нова оправдања. При томе, невеселу слику човечанства налазимо на обе стране: и код мучитеља и код мучених. Први неће, а други не мог̆у да се супротставе злу. Господари су изгубили сваки појам о људскости, они су отеловљење демонских сила историје. У њима се види - ко хоће да види - шта човек никада не би смео да буде. Ни логораши не нуде позитиван одговор: они су озверена гомила, коју господари третирају као марву, умртвљена и покорена, остала без самопоштовања и жеље да се бори. Па, ипак, некаква нада - за историју и за човечанство - сачувана јеу њима. Она се јавља кад се пробуди свест да појединац није случајна и тренутна појава, да мртви и живи чине заједницу у којој се чувају овековечене вредности. Кад се повеже са том снагом, човек постаје свестан себе, постаје удео нечег што га превазилази и чува. Његово постојање добија смисао, скуп појединаца постаје заједница.

Ћосићев роман Грешник сугерише тако могућност другачијег разумевања историје од оног уграђеног у параболе Бајке: она није само низ изневеравања и деградирања вечног сна о правди и слободи него жива ризница вредности. До тог скривеног, другог лица историје, човек долази кад се у њему пробуди свест о припадању заједници, са којом га вежу језик, песме, јунаци, заједничке жртве... Та заједница зове се - народ. Свест о припадности народу усађује у човека „осећање дугог трајања, а не живота од данас до сутра" (Екмечић 2010: 15). Осећај припадања народу - национализам јесте у „основи човекове егзистенције” (Исто), то је идеологија никла из самих основа живота.

За овакво тумачење епизоде о логорашима у Нађмеђеру, осим иманентних херменеутичких налога у тексту романа, упоришта ћемо лако наћи у многобројним есејима и дневничким белешкама Добрице 
Ћосића, као и у његовом друштвеном и политичком деловању. Његов идеолошки интернационализам изгледа никада није био јак као његов национализам. И својим делом и својим животом Ћосић се показао као интелектуалац укорењен у снажно национално осећање. Само из блискости народу, урањањем у биће народа, он је долазио до властите интелектуалне и стваралачке снаге. Није стога чудо што је баш он створио најопсежнији и најзахтевнији покушај романескног обликовања српске историје и судбине.

5. Ћосићево промишљање човековог трајања у времену дато у романима Бајка и Грешник не нуди оптимистичке одговоре ни на националном ни на општељудском плану. Човек је жртва, губитник, бродоломник: двадесети век је то показао у огољеном, драматичном облику. Роман Грешник сугерише „путеве бега” из политичког и историјског вртлога: у крило природе и у крило народа. Природа и народ чине једну целину, праоснову човековог живота. Историја је одвојила човека од те исконске, природне основе постојања. И човек треба да јој се врати. Али, у стварности, у историјској збиљи трајни повратак није могућ. Обасјања која озаре Ћосићеве губитнике и на Јоанидисовом острву, и у паклу Златног врта, тренутна су, али нису неважна: она су путокази и зрнца наде, онај белутак за којим човек наставља да трага у Анђаминој реци-историји.

Јунаци Ћосићевих романа имају снажно изражену „метафизичку свест" (Радуловић 2007), они у себи носе питања о почецима и исходима постојања, о покретачима и циљевима живота. Пада у очи да у тражењу одговора на та питања, ни у Бајии, ни у Времену зла, суштински нема Бога. Барем оног хришћанског - Бога љубави. У мислима Ивана Катића, пишчевог алтер ега у роману, као и неких других јунака, јави се жудња за таквим Богом, али се она брзо заборави, јер њима све говори да такав Бог постоји само као жудња, дакле - одсуство. Тако је и у Бајии. Тамо је место Бога заузео ђаво - пали анђео, борац за ослобађање од божјих закона.

У овој чињеници треба тражити одговоре о природи Ћосићеве космогоније и историозофије, о којој је овде било речи. Али и одговоре о узлетима и понорима Добрице Ћосића - у стваралаштву, политици, историји. Можда и тачку сударања са бићем народа у којем је тражио осмишљење своје борбе, свог стваралаштва и живота.

У романима Бајка и Грешник, као и у Ћосићевим романима уопште, честа су наслањања на хришћанска питања, на Нови завет и Достојевског, али хришћанских одговора нема. Ћосићеви јунаци, као ни њихов творац, нису видели међу људима, у времену и историји, Бога који воли и спасава човека. За њих постоји само Бог моћи, Пантократор, издигнут изнад људских страдања. Тај Бог, осликан на кубету порушене цркве 
у Делфима, једнако је далек комунистичком вернику Петру Бајовићу (који у њему препознаје Стаљина) и енглеским туристима који у њега тупо блену. У целом Ћосићевом делу - у романима, као и у политичкој и мемоарској есејистици, разасута су питања о коренима и смислу постојања, о потреби утемељења и уцеловљења човека. Али, не постоји жива вера у Боїа. У бити, Ћосићева мисао о човеку и свету била је затворена за религиозно и метафичко осмишљавање људског постојања.

Можда баш ту лежи део одговора на питање зашто је национални бард из времена идеолошког једноумља, који је у српску књижевност храбро и субверзивно враћао интересовање за живот и судбину народа, данас потиснут и све чешће оспораван, не само од анационалних интелектуалаца, којима никада није био по вољи, него и од национално утемељених, формираних на трагу његовог литерарног и друштвеног деловања. Или је то само тренутно стање ствари. Одговор ће дати „мајсторско решето" времена.

\section{ЛИТЕРАТУРА}

Деретић, Јован. Срйски роман 1800-1950. Београд: Нолит, 1981. Шт.

Екмечић, Милорад. Дуі̄о кретиање између клања и орања - истиорија Срба у новом веку (1492-1992). Београд: Евро-Ђунти, 2010. Шт.

Јеремић, Драган. „Напомене уз ово издање”. Добрица Ћосић. Време зла - Верник, књ. II. Београд: Филип Вишњић, 2002. Шт.

Крстић, Марко. „Време бајке или како је поражена историја” (предговор). Добрица Ћосић. Бајка. Београд: Српска књижевна задруга, 2010. Шт.

Радуловић, Милан. Роман Добрище Ћосића. Београд: Институт за књижевност и уметност, 2007. Шт.

Скерлић, Јован. „Србија, њена култура и њена књижевност”. Писии и књиіе I. Сабрана дела Јована Скерлића, Београд, 1964. Шт.

Ћосић, Добрица. Време зла - Оййаgник. Београд: Филип Вишњић, 2002. Шт.

Ћосић, Добрица. Пишиеви зайиси 1993-1999. Београд: Службени гласник, 2008. Шт. Ћосић, Добрица. Бајка. Београд: Српска књижевна задруга, 2010. Шт.

Ћосић Вукић, Ана. „Записи о Бајци и коментари” (поговор). Добрица Ћосић. Бајка. Београд: Српска књижевна задруга, 2010. Шт. 
Duško N. Babić

\title{
HISTORY AND ANTI-HISTORY IN DOBRICA ĆOSIĆ'S NOVEL THE SINNER
}

\begin{abstract}
Summary
The paper probes into Dobrica Ćosićs understanding of history in the light of ideas from his novel A Fable. In several phantasmagoric parables, especially in the Anti-History chapter, Ćosić suggests a negative vision of history as an incessant alternation of failed expectations, violence and evil. Mankind's technical and technological progress is not followed by an advancement of the realisation of human dreams of justice and freedom. Two totalitarian systems of the $20^{\text {th }}$ century - Fascism and Bolshevism - indicate that history is not a path towards good and that man has not found the answer to the question what he is and what he never should be. Within the context of a historiosophy set up in this manner, we have analysed the novel The Sinner, from the Time of Evil trilogy. We discuss Ćosić's vision of Serbian history, particularly of that segment in which the author recognised himself as a believer and sinner of communist ideology. Having seen the tragic course of Serbian history in the light of his pessimistic historiosophy, Ćosić suggests the ways of confronting the aimlessness of history, through a return to primordial impulses of life, which he finds in nature and in the depth of the folk soul.
\end{abstract}

